\title{
Adjustment of equations to predict the metabolizable energy of corn for meat type quails
}

\section{Ajustamento de equações para predizer a energia metabolizável do milho para codornas de corte}

\author{
Tiago Junior Pasquetti ${ }^{1 *}$; Paulo Cesar Pozza ${ }^{2}$; Antonio Claudio Furlan²; \\ Leandro Dalcin Castilha ${ }^{3}$; Laura Marcela Diaz-Huepa; \\ Marcelise Regina Fachinello ${ }^{4}$; Simara Márcia Marcato²; Wesley Tanamati ${ }^{5}$
}

\begin{abstract}
The metabolizable energy (ME) determination for foods used in quail diets, through metabolism assays, takes time, infrastructure and financial resources, which makes the development of prediction equations based on proximal composition of foods to estimate the ME values of particular interest. The objective of this study was to adjust the prediction equations of metabolizable energy (ME) of corn for quail. The chemical compositions of 12 maize varieties were determined and a metabolism assay was carried out in order to determine the apparent metabolizable energy (AME) and nitrogen-corrected apparent metabolizable energy (AMEn) of these corn varieties. The values of chemical composition, AME and AMEn, converted to dry matter, were used to adjust the prediction equations. The initial adjustment of simple and multiple linear regression of the AME and AMEn was performed using the values of crude protein $(\mathrm{CP})$, ether extract (EE), neutral (NDF) and acid (ADF) detergent fiber, mineral matter (MM), calcium $(\mathrm{Ca})$ and phosphorus $(\mathrm{P})$ as regressors (full model). To adjust the prediction equations the statistical procedure of simple and multiple linear regression was used, with the technique of indirect elimination (Backward). There was adjustment of 10 prediction equations, in which 5 were for AME and another 5 for AMEn and the $\mathrm{R}^{2}$ values ranged from 0.20 to 0.75 and from 0.21 to 0.78 , respectively. For all adjusted equations, negative correlations for MM were observed, which may be related to its dilutive effect of the gross energy contained in corn. In conclusion, the equations that showed better adjustment were $\mathrm{AME}=$ $5605.46-385.074 \mathrm{CP}+111.648 \mathrm{EE}+48.1133 \mathrm{NDF}+303.924 \mathrm{ADF}-929.931 \mathrm{MM}\left(\mathrm{R}^{2}=0.75\right)$ and $\mathrm{AMEn}=$ $5878.16-403.937 \mathrm{CP}+81.9618 \mathrm{EE}+41.8954 \mathrm{NDF}+303.506 \mathrm{FDA}-901.621 \mathrm{MM}\left(\mathrm{R}^{2}=0.78\right)$.
\end{abstract}

Key words: Chemical composition, correlations, mathematical models

\section{Resumo}

A determinação da energia metabolizável (EM) de alimentos utilizados em dietas para codornas de corte, por meio de ensaios de metabolismo, demanda tempo, infraestrutura e recursos financeiros, o que torna interessante o desenvolvimento de equações de predição da EM baseadas na composição proximal dos

\footnotetext{
${ }^{1}$ Prof., Dept ${ }^{\circ}$ de Zootecnia, Universidade Estadual de Mato Grosso do Sul, UEMS, Aquidauana, MS, Brasil. E-mail: pasquettizoo@, uems.br

2 Profs., Dept ${ }^{\circ}$ de Zootecnia, UEM, Maringá, PR, Brasil. E-mail: pcpozza@uem.br; acfurlan@uem.br; smmarcato2@uem.br

${ }^{3}$ Pós-doutorando em Zootecnia, Universidade Estadual do Oeste do Paraná, UNIOESTE, Bolsista CAPES/PNPD, Marechal Cândido Rondon, PR, Brasil. E-mail: leandrocastilha@hotmail.com

${ }^{4}$ Discentes do Curso de Doutorado no Programa de Pós-Graduação em Zootecnia, PPZ, Universidade Estadual de Maringá, UEM, Maringá, PR, Brasil. E-mail: lauramvz@hotmail.com; lise_faqui@hotmail.com

5 Zootecnista, Coroaves - Frango Maringá, Maringá, PR, Brasil. E-mail: wesleytanamati@hotmail.com

* Author for correspondence
} 
alimentos. Objetivou-se com este trabalho ajustar equações de predição dos valores de EM do milho para codornas de corte. Foi determinada a composição química de 12 diferentes cultivares de milho e realizado um ensaio de metabolismo, com estas cultivares, para determinação da EM aparente (EMA) e EMA corrigida para balanço de nitrogênio (EMAn).De posse da composição química, e dos valores de EMA e EMAn, convertidos para a matéria seca, procedeu-se com o ajuste das equações de predição. $\mathrm{O}$ ajuste inicial dos modelos de regressão linear simples e múltipla, dos dados de EMA e EMAn, foi realizado utilizando-se os valores de proteína bruta (PB), extrato etéreo (EE), fibras em detergentes neutro (FDN) e ácido (FDA), matéria mineral (MM), cálcio $(\mathrm{Ca})$ e fósforo $(\mathrm{P})$ como regressoras (modelo completo). Para o ajustamento das equações de predição, dos valores de EMA e EMAn, foi utilizado o procedimento de regressão linear simples e múltipla, por meio da técnica de eliminação indireta (Backward). Houve ajustamento de 10 equações de predição da EM do milho, sendo 5 para EMA e 5 para EMAn, cujos valores de $\mathrm{R}^{2}$ variaram de 0,20 a 0,75 e de 0,21 a 0,78 , respectivamente. Em todas as equações ajustadas observouse correlação negativa para a matéria mineral, o que pode estar associado ao seu efeito diluente da energia bruta contida nos milhos. Conclui-se que as equações que apresentaram melhor ajustamento foram EMA $=5605,46-385,074 \mathrm{~PB}+111,648 \mathrm{EE}+48,1133 \mathrm{FDN}+303,924 \mathrm{FDA}-929,931 \mathrm{MM}\left(\mathrm{R}^{2}=0,75\right)$ e EMAn $=$ $5878,16-403,937 \mathrm{~PB}+81,9618 \mathrm{EE}+41,8954 \mathrm{FDN}+303,506 \mathrm{FDA}-901,621 \mathrm{MM}\left(\mathrm{R}^{2}=0,78\right)$.

Palavras-chave: Composição química, correlações, modelos matemáticos

\section{Introduction}

Brazil is the fifth largest producer of quail meat (SILVA, 2009). Quail production has been growing in the country due to an increase in automation and new ways to commercialize meat and eggs. The production of meat quails is conquering its space, especially because it does not require onerous investment in facilities. On the other hand, the food still contributes to a considerable portion of the production costs.

Considering the feedstuffs used in quail diets, corn contributes the greatest amount of metabolizable energy (ME). However, differences are observed among the nutrient content of corn found in feed composition tables and those values determined in laboratories, which can be attributed, among other factors, to the genetic material cultivated (SAKOMURA; SILVA, 1998). This variation in the chemical composition of corn can provide different $\mathrm{ME}$ values compared to those found in feed composition tables.

The ME results from the ratio between the chemical and physical characteristics of the feed with the anatomical and physiological characteristics of birds, which directly influence the digestive processes and absorption. Besides the animal, the raw material used in the feed formulation should also be considered, because the origin of the cultivar, storage, granulometry, chemical composition, and other factors, directly influence the efficiency of nutrient (SILVA et al., 2009) and energy utilization by quails.

The determination of ME of corn for quails, through metabolism assays, requires time, facilities and financial resources, which makes the development of prediction equations based on proximal composition of feeds of particular interest, as, according to Zonta et al. (2004), this can be routinely determined in laboratories, as a quick, practical and economic alternative.

However, the lack of information about the apparent ME (AME) and nitrogen-corrected apparent metabolizable energy (AMEn) of corn for meat quail makes data compilation to adjust prediction equations complicated, making initial in vivo studies necessary for the subsequent adjustment of equations.

Several equations to predict the ME of corn have been adjusted for other species and considering the constant evolution and importance of quail production, the development and adjustment of these equations is important to increase the precision in formulating these diets. Thus, the objective of this study was to adjust the prediction equations of ME 
of corn for meat type quail.

\section{Material and Methods}

The experiment was carried out in the Fazenda Experimental de Iguatemi (FEI)/Universidade Estadual de Maringá (UEM). A total of 260 male meat type quails, aged 22 days old were used and allotted in a completely randomized design, with 13 treatments, 4 replicates and 5 birds per experimental unit.

Treatments consisted of 12 batches of corn, which replaced $20 \%$ of the basal diet (BD), which was formulated based on corn and soybean meal (Table 1), using the chemical composition of feeds proposed by Rostagno et al. (2011).

The experiment lasted for 10 days, using 5 for cage and feed adaptation and the other 5 for total excreta collection. The birds had free access to feed and water. In order to obtain the average feed intake of each experimental unit, feed was weighed at the beginning and end of the total collection period. Ferric oxide $(2 \%)$ was used in order to determine the beginning and the end of the collection period.

Table 1. Centesimal, chemical and energetic composition of the basal diet.

\begin{tabular}{|c|c|}
\hline Item $(\%)$ & Amount $(\mathrm{kg})$ \\
\hline Corn & 50.73 \\
\hline Soybean meal & 41.82 \\
\hline Soybean oil & 3.90 \\
\hline Limestone & 0.30 \\
\hline Dicalcium phosphate & 1.55 \\
\hline Salt & 0.46 \\
\hline DL-Methionine & 0.43 \\
\hline L-Lysine $\mathrm{HCl}$ & 0.35 \\
\hline L-Threonine & 0.04 \\
\hline Vitamin-trace Mineral Premix ${ }^{1}$ & 0.40 \\
\hline $\mathrm{BHT}^{2}$ & 0.02 \\
\hline
\end{tabular}

Calculated content

$\begin{array}{lr}\text { Metabolizable energy }\left(\mathrm{kcal} \mathrm{kg}^{-1}\right) & 3,036\end{array}$

$\begin{array}{lr}\text { Crude protein }(\%) & 23.50\end{array}$

$\begin{array}{lr}\text { Calcium (\%) } & 0.610\end{array}$

Available phosphorus (\%) $\quad 0.410$

$\begin{array}{ll}\text { Sodium (\%) } & 0.200\end{array}$

$\begin{array}{ll}\text { Potassium (\%) } & 0.914\end{array}$

$\begin{array}{ll}\text { Chlorine (\%) } & 0.324\end{array}$

$\begin{array}{lr}\text { Digestible Lysine (\%) } & 1.450\end{array}$

$\begin{array}{ll}\text { Digestible Threonine (\%) } & 0.943\end{array}$

Digestible Methionine + Cystine (\%) 1.044

$\begin{array}{ll}\text { Digestible Tryptophan (\%) } & 0.294\end{array}$

DEB $\left(\mathrm{mEq} \mathrm{kg}^{-1}\right)^{3} \quad 229.33$

${ }^{1}$ Guaranteed levels per kg of product: Vit.A - 4,500,000 UI; Vit.D3 - 1,250,000 UI; Vit.E - 4,000 mg; Vit.B1 - 278 mg; Vit.B2 - 2,000 mg; Vit.B6 - 525 mg; Vit.B12 - 5,000 mcg; Vit.K3 - 1.007 mg; Calcium Pantothenate - 4,000 mg; Niacin - 10,000 mg; Choline - 140,000 mg; Antioxidant - 5,000 mg; Zinc - 31,500 mg; Iron - 24,500 mg; Manganese - 38,750 mg; Copper - 7,656 mg; Cobalt - 100 mg; Iodine - 484 mg; Selenium - 127 mg. ${ }^{2}$ BHT (Butylated hydroxytoluene); ${ }^{3}$ Diet Eletrolitic Balance. 
Temperature and humidity values were recorded twice a day ( 8 and $5 \mathrm{pm}$ ) by a maximum and minimum thermometer installed inside of the experimental facilities.

The birds were housed in wired cages $(20 \mathrm{~cm}$ wide $\times 33 \mathrm{~cm}$ deep x $25 \mathrm{~cm}$ tall), equipped with nipple and self-feeders. The trays for excreta collection were covered with plastic bags, identified, and removed at each collection (12 hours).

The collected material, after the removal of feather waste, feed and peeling skin, was packed in plastic bags and stored in a freezer until the end of the total collection period.

The excreta were thawed, homogenized, weighed and dried in a forced air oven for 72 hours at $55^{\circ} \mathrm{C}$. Subsequently, the samples were milled and sent to the Animal Nutrition Lab-UEM, together with diets and feeds, to determine the dry matter (DM), crude protein $(\mathrm{CP})$, ether extract (EE), neutral detergent fiber (NDF), acid detergent fiber (ADF), mineral matter (MM), calcium (Ca) and phosphorus (P), which was performed as described by Silva and Queiroz (2005).

Gross energy (GE) analysis of experimental diets, corn batches and excreta were held in COMCAPUEM, in which a Parr ${ }^{\circledR}$ calorimeter, model 6200, was used.

The AME and AMEn were obtained using the equation proposed by Matterson et al. (1965) and the coefficients of metabolizability of GE for the AME (CMGE) and AMEn (CMGEn) were determined.

Statistical analyses were performed with the Sistema de Análises Estatísticas e Genéticas SAEG, developed by the Federal University of
Viçosa (UFV, 2005). The Student Newman Keuls test was used, to evaluate the CMGE and CMGEn of corn cultivars. For adjustment of the prediction equations, for the values of AME and AMEn, we used the simple and multiple linear regression procedure through indirect disposal techniques (Backward), in which CP, EE, NDF, ADF, MM, Ca and $\mathrm{P}$ were used as a regressive fit to the models.

The significance of the parameters of the regression models for the " $t$ " partial test was the main criteria used to select the regressive variables. Non-significant parameters were removed from the model and the analysis was reprocessed.

The estimation of the parameters of the regression models was performed by the method of least squares. The goodness of fit of the models with intercept to the metabolizable energy data was assessed by the coefficient of determination $\left(\mathrm{R}^{2}\right)$. The 0.05 significance level was used for all hypothetical tests.

\section{Results and Discussion}

The corn batches (Table 2) showed a minimum DM value of $88.23 \%$, which is in agreement with a good moisture profile, because the drying of the corn grains to reduce the moisture content below 13\% has been recommended as a safe procedure for storage (MAZZUCO et al., 2002). In this regard, Henz et al. (2013) reported that the moisture content of grains is considered an important parameter, because in high humidity conditions and long-term storage, as well as high environmental temperature, fungi contamination can occur, which produce mycotoxins that causes metabolic disorders in animals. 
Table 2. Chemical composition of different corn batches, as feed basis.

\begin{tabular}{lcccccccc}
\hline Corn & $\mathrm{DM}^{1}(\%)$ & $\mathrm{CP}^{2}(\%)$ & $\mathrm{EE}^{3}(\%)$ & $\mathrm{NDF}^{4}(\%)$ & $\mathrm{ADF}^{5}(\%)$ & $\mathrm{MM}^{6}(\%)$ & $\mathrm{Ca}^{7}(\%)$ & $\mathrm{P}^{8}(\%)$ \\
\hline 1 & 89.44 & 7.62 & 4.01 & 12.62 & 3.87 & 0.89 & 0.010 & 0.209 \\
2 & 88.73 & 7.56 & 4.44 & 11.75 & 3.24 & 0.69 & 0.016 & 0.201 \\
3 & 88.49 & 7.63 & 4.20 & 15.83 & 4.02 & 0.88 & 0.012 & 0.237 \\
4 & 89.50 & 8.00 & 2.95 & 17.27 & 3.66 & 0.85 & 0.011 & 0.234 \\
5 & 89.28 & 7.06 & 3.79 & 15.79 & 4.33 & 1.79 & 0.013 & 0.215 \\
6 & 89.05 & 6.85 & 3.72 & 10.89 & 2.78 & 0.99 & 0.010 & 0.262 \\
7 & 88.77 & 7.58 & 3.55 & 15.59 & 3.55 & 0.96 & 0.013 & 0.229 \\
8 & 88.94 & 8.43 & 1.98 & 15.33 & 4.39 & 0.66 & 0.011 & 0.227 \\
9 & 89.75 & 7.02 & 1.61 & 17.87 & 3.17 & 0.96 & 0.011 & 0.207 \\
10 & 88.23 & 7.92 & 1.83 & 14.79 & 3.06 & 1.07 & 0.010 & 0.235 \\
11 & 89.09 & 7.53 & 2.41 & 15.79 & 4.02 & 1.04 & 0.012 & 0.250 \\
12 & 88.82 & 7.21 & 4.13 & 15.43 & 3.28 & 1.18 & 0.012 & 0.234 \\
\hline Average & 89.01 & 7.53 & 3.22 & 14.91 & 3.61 & 1.00 & 0.01 & 0.23 \\
SD & 0.42 & 0.43 & 0.97 & 2.02 & 0.50 & 0.28 & 0.002 & 0.017 \\
Range & 1.52 & 1.41 & 2.83 & 6.98 & 1.61 & 1.13 & 0.006 & 0.061 \\
\hline
\end{tabular}

${ }^{1-}$ Dry Matter; ${ }^{2-}$ Crude Protein; ${ }^{3-}$ Ether Extract; ${ }^{4-}$ Neutral Detergent Fiber; ${ }^{5-}$ Acid Detergent Fiber; ${ }^{6-}$ Mineral Matter; ${ }^{7-}$ Calcium; 8-Phosphorus, ${ }^{9-}$ Standar Deviation.

The lowest CP obtained (6.85\%) was lower than those presented by the National Research Council - NRC (2012) and Rostagno et al. (2011). However, the largest value $(8.43 \%)$ is close to the $8.24 \%$ reported by NRC (2012). These differences in the CP content may be related, among other variables, to agronomic practices employed in corn cultivating (CASTRO et al., 2009), in which the nitrogen fertilization can influence the CP levels in the grain (EYNG et al., 2009). According to Vieira et al. (2007), this variation in the CP content of corn should be considered relevant because hybrids grown in the same conditions, but with different doses of nitrogen fertilization, can influence the composition of dietary CP.

Ether extract also showed a high variation between corn batches, since the range between the smallest and the largest value was $2.83 \%$, which was higher than the value of $0.77 \%$ observed by Vieira et al. (2007).

In addition to the differences observed between corns (DM, CP and EE), there was a large range
(Table 2) for the cell wall constituents (NDF and ADF). These results are in agreement with those found by Pelizzeri et al. (2013), who reported that the ADF content, among 48 evaluated samples, showed the highest coefficient of variation, followed by CF, NDF, EE and MM. The MM also had a large range (1.13\%), which may partially explain the variation in $\mathrm{Ca}$ and $\mathrm{P}$ content of corn batches.

The range in the chemical composition of the studied corn batches may be related to genetic material, soil, fertilization and climate (ROCHA JUNIOR et al., 2003). Similarly, this variation shows that the use of fixed values in feed formulation programs can cause imbalances in the diets (PELIZZERI et al., 2013).

This variation in chemical composition also contributed to the differences in GE values (3657

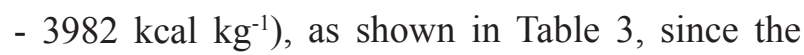
chemical composition of the feed is the major GE determinant. 
Table 3. Energetic values and coefficients of metabolizability of energy of different corns for meat type quails, as feed basis.

\begin{tabular}{lccccc}
\hline Corn & $\mathrm{GE}^{1}\left(\mathrm{kcal} \mathrm{kg}^{-1}\right)$ & $\mathrm{AME}^{2}\left(\mathrm{kcal} \mathrm{kg}^{-1}\right)$ & $\mathrm{AMEn}^{3}\left(\mathrm{kcal} \mathrm{kg}^{-1}\right)$ & $\mathrm{CMGE}^{4}(\%)$ & $\mathrm{CMGEn}^{5}(\%)$ \\
\hline 1 & 3,935 & 3,513 & 3,390 & $89.28^{\mathrm{a}}$ & $77.05^{\mathrm{a}}$ \\
2 & 3,966 & 3,401 & 3,317 & $85.74^{\mathrm{a}}$ & $74.21^{\mathrm{a}}$ \\
3 & 3,971 & 3,534 & 3,465 & $88.99^{\mathrm{a}}$ & $77.20^{\mathrm{a}}$ \\
4 & 3,982 & 3,469 & 3,382 & $87.11^{\mathrm{a}}$ & $76.01^{\mathrm{a}}$ \\
5 & 3,657 & 3,168 & 3,100 & $86.64^{\mathrm{a}}$ & $75.67^{\mathrm{a}}$ \\
6 & 3,900 & 3,228 & 3,208 & $82.76^{\mathrm{a}}$ & $73.26^{\mathrm{a}}$ \\
7 & 3,914 & 3,377 & 3,357 & $86.28^{\mathrm{a}}$ & $76.13^{\mathrm{a}}$ \\
8 & 3,934 & 3,195 & 3,184 & $81.22^{\mathrm{a}}$ & $71.99^{\mathrm{a}}$ \\
9 & 3,899 & 3,344 & 3,322 & $85.76^{\mathrm{a}}$ & $76.46^{\mathrm{a}}$ \\
10 & 3,862 & 2,726 & 2,701 & $70.59^{\mathrm{b}}$ & $61.69^{\mathrm{b}}$ \\
11 & 3,909 & 3,357 & 3,351 & $85.89^{\mathrm{a}}$ & $76.37^{\mathrm{a}}$ \\
12 & 3,942 & 3,411 & 3,297 & $86.53^{\mathrm{a}}$ & $74.29^{\mathrm{a}}$ \\
\hline $\mathrm{CV}(\%)^{6}$ & \multicolumn{7}{c}{} & 4.07 & 3.59 \\
\hline
\end{tabular}

Means followed by different letters in the column differ by Student Newman Keuls Test $(\mathrm{P}<0.05) .{ }^{1-}$ Gross Energy, ${ }^{2-}$ Apparent Metabolizable Energy, ${ }^{3-N i t r o g e n-c o r r e c t e d ~ A p p a r e n t ~ M e t a b o l i z a b l e ~ E n e r g y . ~}{ }^{4-}$ Coefficients of Metabolizability of Gross Energy,

${ }^{5-}$ Coefficients of Metabolizability of Gross Energy Corrected for Nitrogen Balance, ${ }^{6-}$ Coefficient of variation.

Differences were observed $(\mathrm{P}<0.05)$ between the CMGE and CMGEn, in which batch 10 showed a lower coefficient than the others (Table 3). The CMGE values of the other corn cultivars were similar, and cultivars 1 and 3 showed values close to that obtained by Furlan et al. (1998), who observed a value of $88.99 \%$ for ground corn when working with Japanese quail.

AME and AMEn (Table 3) ranged from 2726 to $3534 \mathrm{kcal} \mathrm{kg}^{-1}$ and from 2701 to $3465 \mathrm{kcal} \mathrm{kg}^{-1}$, respectively. The average AMEn values were $1.63 \%$ lower compared to AME. This is normal when the energy values are determined with growing birds due to positive nitrogen retention for protein tissue deposition, and can be more evident when the values are corrected for nitrogen balance (NERY et al., 2007). Thus, the correction for nitrogen balance reduces the variation between AME values of the ingredients evaluated under different conditions (LOPEZ; LEESON, 2008).

The AMEn showed a greater range than in the study by Vieira et al. (2007) in which, evaluating 45 corn hybrids for broilers, it was found that AMEn ranged from 3405 to $4013 \mathrm{kcal} \mathrm{kg}^{-1}$. The authors also observed high variability in the chemical composition of hybrid corn, and reported that the concentration of nutrients in the feed was directly related to its energy levels.

The chemical composition results (Table 2) and ME (Table 3) show the importance of adequate knowledge before use in feed formulations for meat type quails, as the use of feed composition tables is often, but not always, adequate for diet formulation.

The matrix of correlations between chemical composition and energy content (Table 4) obtained 
from the adjustment of the prediction equations showed negative correlations of $\mathrm{MM}$ related to AME and AMEn. In this case, the energy content of the feed is influenced by the reduction of organic matter, which provides energy contribution to the feed (NASCIMENTO et al., 2009).

Table 4. Matrix of correlation between metabolizable energy values and chemical components of the different studied corns. ${ }^{1}$

\begin{tabular}{|c|c|c|c|c|c|c|c|c|}
\hline & AME & $\mathrm{CP}^{1}$ & $\mathrm{EE}^{2}$ & $\mathrm{NDF}^{3}$ & $\mathrm{ADF}^{4}$ & $\mathrm{MM}^{5}$ & $\mathrm{Ca}^{6}$ & $\mathrm{P}^{7}$ \\
\hline & \multicolumn{8}{|c|}{ Apparent Metabolizable Energy - AME } \\
\hline AME & 1.0000 & - & - & - & - & - & - & - \\
\hline $\mathrm{CP}$ & 0.0614 & 1.0000 & - & - & - & - & - & - \\
\hline EE & 0.3176 & -0.3021 & 1.0000 & - & - & - & - & - \\
\hline NDF & 0.0589 & 0.1740 & -0.5079 & 1.0000 & - & - & - & - \\
\hline ADF & 0.2869 & 0.4209 & 0.0006 & 0.3493 & 1.0000 & - & - & - \\
\hline MM & -0.4467 & -0.5367 & 0.1244 & 0.1894 & 0.1564 & 1.0000 & - & - \\
\hline $\mathrm{Ca}$ & 0.1995 & -0.0843 & 0.5045 & -0.1009 & 0.1155 & 0.0302 & 1.0000 & - \\
\hline \multirow[t]{2}{*}{$\mathrm{P}$} & -0.1456 & -0.0105 & -0.0748 & -0.0897 & -0.1602 & 0.0281 & -0.4065 & 1.0000 \\
\hline & \multicolumn{8}{|c|}{ Nitrogen-Corrected Apparent Metabolizable Energy - AMEn } \\
\hline AMEn & 1.0000 & - & - & - & - & - & - & - \\
\hline $\mathrm{CP}$ & 0.0406 & 1.0000 & - & - & - & - & - & - \\
\hline $\mathrm{EE}$ & 0.2640 & -0.3021 & 1.0000 & - & - & - & - & - \\
\hline NDF & 0.0742 & 0.1740 & -0.5079 & 1.0000 & - & - & - & - \\
\hline $\mathrm{ADF}$ & 0.2841 & 0.4209 & 0.0006 & 0.3493 & 1.0000 & - & - & - \\
\hline MM & -0.4611 & -0.5367 & 0.1244 & 0.1894 & 0.1564 & 1.0000 & - & - \\
\hline $\mathrm{Ca}$ & 0.2024 & -0.084 & 0.5045 & -0.1009 & 0.1155 & 0.0302 & 1.0000 & - \\
\hline $\mathrm{P}$ & -0.0866 & -0.0105 & -0.0748 & -0.0897 & -0.1602 & 0.0281 & -0.4065 & 1.0000 \\
\hline
\end{tabular}

${ }^{1-}$ Crude Protein, ${ }^{2-}$ Ether Extract, ${ }^{3-}$ Neutral Detergent Fiber, ${ }^{4-}$ Acid Detergent Fiber, ${ }^{5-}$ Mineral Matter, ${ }^{6-}$ Calcium, ${ }^{7-}$ Phosphorus.

Ether extract correlated positively with AME and AMEn and, according to Zhou et al. (2010), feeds containing more lipids or carbohydrates have higher values of ME compared to those that are high in protein or fiber. On the other hand, the NDF and ADF were highly correlated with the values of ME.

Regarding the adjusted prediction equations (Table 5), it can be observed that the prediction models with the largest number of independent variables showed higher coefficients of determination $\left(\mathrm{R}^{2}\right)$, with values of 0.75 (AME) and 0.78 (AMEn) for equations with five variables. The same response was obtained by Rodrigues et al. (2001), when prediction equations of AMEn of corn and corn by-products for broiler chicks were adjusted. 
Table 5. Prediction equations of apparent metabolizable energy (AME), and nitrogen-corrected apparent metabolizable energy (AMEn), based on chemical composition of different corns for meat type quails.

\begin{tabular}{|c|c|c|c|c|c|c|c|c|c|}
\hline \multicolumn{10}{|c|}{ Prediction equations of AME } \\
\hline$n^{\circ}$ & Constant & $\mathrm{CP}^{1}$ & $\mathrm{EE}^{2}$ & $\mathrm{NDF}^{3}$ & $\mathrm{ADF}^{4}$ & $\mathrm{MM}^{5}$ & $\mathrm{Ca}^{6}$ & $\mathrm{P}^{7}$ & $\mathrm{R}^{2}$ \\
\hline 1 & 5605.46 & -385.074 & 111.648 & 48.1133 & 303.924 & -929.931 & - & - & 0.75 \\
\hline 2 & 6316.41 & -390.652 & 58.4515 & - & 368.138 & -863.921 & - & - & 0.67 \\
\hline 3 & 7002.77 & -455.059 & - & - & 395.744 & -901.168 & - & - & 0.62 \\
\hline 4 & 3504.84 & - & - & - & 184.993 & -453.563 & - & - & 0.33 \\
\hline 5 & 4198.52 & - & - & - & - & -402.091 & - & - & 0.20 \\
\hline \multicolumn{10}{|c|}{ Prediction equations of AMEn } \\
\hline $\mathrm{n}^{\mathrm{o}}$ & Constant & $\mathrm{CP}$ & $\mathrm{EE}$ & $\mathrm{NDF}$ & $\mathrm{ADF}$ & MM & $\mathrm{Ca}$ & $\mathrm{P}$ & $\mathrm{R}^{2}$ \\
\hline 1 & 5878.16 & -403.937 & 81.9618 & 41.8954 & 303.506 & -901.621 & - & - & 0.78 \\
\hline 2 & 6881.10 & -469.351 & - & 19.3089 & 360.566 & -906.948 & - & - & 0.71 \\
\hline 3 & 6915.73 & -488.065 & - & - & 376.253 & -866.852 & - & - & 0.68 \\
\hline 4 & 3471.56 & - & - & - & 168.741 & -426.126 & - & - & 0.34 \\
\hline 5 & 4104.30 & - & - & - & - & -379.177 & - & - & 0.21 \\
\hline
\end{tabular}

${ }^{1-}$ Crude Protein, ${ }^{2-E}$ ther Extract, ${ }^{3-}$ Neutral Detergent Fiber, ${ }^{4-}$ Acid Detergent Fiber, ${ }^{5-}$ Mineral Matter, ${ }^{6-}$ Calcium, ${ }^{7-}$ Phosphorus.

According to Pozza et al. (2008), equations consisting of up to 4 chemical composition variables require less time, the determinations are easier and more economical, and they can be used with greater ease. Similarly, Rodrigues et al. (2001) noted that equations with large numbers of predictors variables, although potentially being more accurate in estimations, may become unfeasible, since the determination of some components such as the geometric mean diameter and density of the feed, in practical terms, is not often possible. However, the regressive variables used in this study can be considered suitable, since it does not require a long time for measurements and can be used easily; in addition, the geometric mean diameter and the density of the corn cultivars were not used as regressive variables to adjust the prediction equations.

The equations $\mathrm{AME}=5605.46-385.074 \mathrm{CP}$ $+111.648 \mathrm{EE}+48.1133 \mathrm{NDF}+303.924 \mathrm{ADF}$ 929.931 MM and AMEn= 5878.16 - 403.937CP $+81.9618 \mathrm{EE}+41.8954 \mathrm{NDF}+303.506 \mathrm{ADF}$ -
901.621MM were the most effective in predicting $\mathrm{ME}$, because they showed a greater $\mathrm{R}^{2}$.

However, there is a need to evaluate the performance of prediction models in a set of independent data, in order to assess the accuracy of these models (PELIZZERI et al., 2013). These authors also found that the accuracy of the equations cannot only be attributed to the coefficient of determination. Similarly, Oliveira and Warpechowski (2009) reported that most of the models have good predictive power for the data set in which they were derived; however, there are few studies comparing the behavior of prediction models in sets of independent data.

Based on the results obtained, we can infer that variations in the chemical composition of corn can provide different values for AME and AMEn. Thus, it is necessary to conduct research to evaluate the chemical composition and the ME value of corn, and to adjust and validate equations to predict the ME values, in order to optimize the feed formulation for meat type quails. 


\section{Conclusion}

The equations that showed better adjustment in predicting the metabolizable energy of corn for meat type quails were $\mathrm{AME}=5605.46-385.074 \mathrm{CP}$ $+111.648 \mathrm{EE}+48.1133 \mathrm{NDF}+303.924 \mathrm{ADF}-$ 929.931MM and AMEn= 5878.16 - 403.937CP + 81.9618EE + 41.8954NDF + 303.506ADF 901.621MM.

\section{References}

CASTRO, M. V. L.; NAVES, M. M. V.; OLIVEIRA, J. P.; FROES, L. O. Rendimento industrial e composição química de milho de alta qualidade protéica em relação a híbridos comerciais. Pesquisa Agropecuária Tropical, Goiás, v. 39, n. 3, p. 233-242, 2009.

EYNG, C.; NUNES, R. V.; POZZA, P. C.; POZZA, M. S. S.; NUNES, C. G. V.; NAVARINI, F. C.; SILVA, W. T. M.; APPELT, M. D. Composição química e valores energéticos de cultivares de milho para aves. Revista Brasileira de Saúde e Produção Animal, Salvador, v. 10, n. 1, p. 60-72, 2009.

FURLAN, A. C.; ANDREOTTI, M. O.; MURAKAMI, A. E.; SCAPINELLO, C.; MOREIRA, I.; FRAIHA, M.; CAVALIERI, F. L. B. Valores energéticos de alguns alimentos determinados com codornas japonesas (Coturnix coturnix japonica). Revista Brasileira de Zootecnia, Viçosa, v. 27, n. 6, p. 1147-1150, 1998.

HENZ, J. R.; NUNES, R. V.; POZZA, P. C.; FURLAN, A. C.; SCHERER, C.; EYNG, C.; SILVA, W. T. M. Valores energéticos de diferentes cultivares de milho para aves. Semina Ciências Agrárias, Londrina, v. 34, n. 5, p. 2403-2414, 2013.

LOPEZ, G.; LEESON, S. Assessment of the nitrogen correction factor in evaluating metabolizable energy of corn and soybean meal in diets for broilers. Poultry Science, Guelph, v. 87, n. 2, p. 298-306, 2008.

MATTERSON, L. D.; POTTER, L. M.; STUTZ, M. W.; SINGSEN, E. P. The metabolizable energy of feed ingredients for chickens. University of Connecticut, Agricultural Experiment Station, Research Report, Storrs, Connecticut, v. 7, n. 1, p. 11-14, 1965.

MAZZUCO, H.; LORINI, I.; BRUM, P. A. R.; ZANOTTO, D. L.; BARIONI JUNIOR, W.; AVILA, V. S. Composição química e qnergética do milho com diversos níveis de umidade na colheita e diferentes temperaturas de secagem para frangos de corte. Revista Brasileira de Zootecnia, Viçosa, v. 31, n. 6, p. 2216-2220, 2002.
NASCIMENTO, G.A. J.; RODRIGUES, P. B.; FREITAS, R. T. F.; BERTECHINI, A. G.; LIMA, R. R.; PUCCI, L. E. A. Equações de predição para estimar os valores energéticos de alimentos concentrados de origem vegetal para aves utilizando a metanálise. Revista Brasileira de Zootecnia, Viçosa, v. 38, n. 7, p. 1265-1271, 2009.

NATIONAL RESEARCH COUNCIL - NRC. Nutrient requirements of swine. 11. ed. Washington, D. C.: National Academy Press, 2012. 400 p.

NERY, L. R.; ALBINO, L. F. T.; ROSTAGNO, H. S.; CAMPOS, A. M. A.; SILVA, C. R. Valores de energia metabolizável de alimentos determinados com frangos de corte. Revista Brasileira de Zootecnia, Viçosa, v. 36, n. 5, p. 1354-1358, 2007.

OLIVEIRA, V.; WARPECHOWSKI, M. Avaliação de modelos para predição da energia metabolizável do milho para aves. Ciência Rural, Santa Maria, v. 39, n. 5, p. 1514-1520, 2009.

PELIZZERI, R. N.; POZZA, P. C.; OLIVEIRA, N. T. E.; SOMENSI1, M. L.; FURLAN, A. C.; NEUMANN, M. E. Avaliação de modelos de predição da energia metabolizável do milho para suínos. Arquivos Brasileiros de Medicina Veterinária e Zootecnia, Belo Horizonte, v. 65, n. 2, p. 460-468, 2013.

POZZA, P. C.; GOMES, P. C.; DONZELE, J. L.; ROSTAGNO, H. S.; POZZA, M. S. S.; NUNES, R. V. Composição química, digestibilidade e predição dos valores energéticos da farinha de carne e ossos para suínos. Acta Scientiarum Animal Science, Maringá, v. 30, n. 1, p. 33-40, 2008.

ROCHA JUNIOR, V. R.; VALADARES FILHO, S. C.; BORGES, A. M.; DETMANN, E.; MAGALHÃES, K. A.; VALADARES, R. F. D.; GONÇALVES, L. C.; CECON, P. R. Estimativa do valor energético dos alimentos e validação das equações propostas pelo NRC. Revista Brasileira de Zootecnia, Viçosa, v. 32, n. 2, p. 480-490, 2003.

RODRIGUES, P. B.; ROSTAGNO, H. S.; ALBINO, L. F. T.; GOMES, P. C.; BARBOZA, W. A.; SANTANA, R. T. Valores energéticos do milheto, do milho e subprodutos do milho, determinados com frangos de corte e galos adultos. Revista Brasileira de Zootecnia, Viçosa, v. 30, n. 6, p. 1767-1778, 2001.

ROSTAGNO, H. S.; ALBINO, L. F. T.; DONZELE, J. L.; GOMES, P. C.; OLIVEIRA, R. F. M.; LOPES, D. C.; FERREIRA, A. S.; BARRETO, S. L. T.; EUCLIDES, R. F. Tabelas brasileiras para aves e suinos: composição de alimentos e exigências nutricionais. 3. ed. Viçosa, MG: Universidade Federal de Viçosa, 2011. 252 p. 
SAKOMURA, N. K.; SILVA, R. Conceitos inovadores aplicáveis à nutrição de não ruminantes. Cadernos Técnicos da Escola de Veterinária da UFMG, Minas Gerais, n. 22, p. 125-146, 1998.

SILVA, D. J.; QUEIROZ, A. C. Análise de alimentos: métodos químicos e biológicos. 3. ed. Viçosa: UFV, 2005. $235 \mathrm{p}$.

SILVA, J. H. V. Tabelas para codornas Japonesas e Européias: tópicos especiais, composição de alimento e exigências nutricionais. Jaboticabal: Ed. Funep, 2009. $107 \mathrm{p}$.

SILVA, R. M.; FURLAN, A. C.; TON, A. P. S.; MARTINS, E. N.; SCHERER, C.; MURAKAMI, A. E. Exigência nutricional de cálcio de fósforo de codornas de corte em crescimento. Revista Brasileira de Zootecnia, Viçosa, v. 38, n. 8, p. 1509-1517, 2009.

UNIVERSIDADE FEDERAL DE VIÇOSA - UFV. Central de processamento de dados - UFV/CPD. SAEG - Sistema para análises estatísticas. Versão 9. 1. Viçosa, 2005. $301 \mathrm{p}$.
VIEIRA, R. O.; RODRIGUES, P. B.; FREITAS, R. T. F.; NASCIMENTO, G. A. J.; SILVA, E. L.; HESPANHOL, R. Composição química e energia metabolizável de híbridos de milho para frangos de corte. Revista Brasileira de Zootecnia, Viçosa, v. 36, n. 4, p. 832-838, 2007.

ZHOU, Z.; WAN, H. F.; LI, Y.; CHEN, W.; QI, Z. L.; PENG, P.; PENG, J. The influence of the amylopectin/amylose ratio in samples of corn on the true metabolizable energy value for ducks. Animal Feed Science and Techonology, Amsterdam, v. 157, n. 1, p. 99-103, 2010.

ZONTA, M. C. M.; RODRIGUES, P. B.; ZONTA, A.; FREITAS, R. T. F.; BERTECHINI, A. G.; FIALHO, E. T.; PEREIRA, C. R. Energia metabolizável de ingredientes proteicos determinada pelo método de coleta e por equações de predição. Ciência e Agrotecnologia, Lavras, v. 28, n. 6, p. 1400-1407, 2004. 